\title{
A Comparative Study of Zakah and Modern Taxation
}

\author{
Nur Barizah Abu Bakar \\ Lecturer - Department of Accounting, \\ Kulliyyah of Economics and Management Sciences of \\ International Islamic University Malaysia (IIUM). \\ Kuala Lumpur, Malaysia \\ E-mail: barizah@iiu.edu.my \\ Abdul Rahim Abdul Rahman \\ Associate Professor - Department of Accounting, \\ Kulliyyah of Economics and Management Sciences \\ International Islamic University Malaysia (IIUM). \\ Kuala Lumpur, Malaysia
}

\begin{abstract}
This paper critically discusses the concept of zakah and taxation. The main objective of the paper is, first, to compare and contrast zakah and taxation, especially on the legal, economic, social, ethical and spiritual aspects. Secondly, the paper aims to examine issues related to the implementation of zakah in modern time by reviewing the practices of zakah and taxation in the early Islamic period and exploring the issues in the context of Malaysia. The paper indicates that zakah greatly differs from the taxation system. Zakah aims not only to achieve religious merit but also to become part of the modern state fiscal policies and share a greater role in removing inequalities in the society. The paper argues that there may be lack of proper implementation of zakah in Muslim countries which limits the success of the noble aims of zakah. Finally, the paper indicates the urgent need for education and political will of modern governments to ensure the success and survival of zakah.
\end{abstract}

\section{Introduction}

Zakah is "that portion of a man's wealth which is designated for the poor" (Sayyid Sabiq, 1991, p.1). It is also defined as: "a compulsory levy imposed on the Muslims so as to take surplus money or wealth from the comparatively well-to-do members of the Muslim Society and give it to the destitute and needy" (Zaim, 1989, p.101). Economically, zakah in theory will result in economic prosperity as zakah is paid from those who have surplus, to the poor. This will improve the poor's purchasing power, 
which may lead to a higher demand on goods (Ahmad, 1977, p.80). 'Purification' is also among the objectives and purposes of zakah. This includes purifying the wealth of the contributor because in the wealth of the relatively well-to-do, some portions of it are the right (due) of the others ${ }^{(1)}$. The Islamic concept of wealth viewed that all wealth bestowed by Allah as a Trust (Amanah). The real owner of wealth is Allah alone (Abdalati, 1980, p.128).

Conditions for zakatable assets and income are specified and determined by Islamic Shariah. Zakah is traditionally levied not only on money, but also on commercial goods or merchandise, agricultural produce, livestock, minerals including gold, silver and treasure trove. Applying the methodology of qiyas (analogical reasoning), the emerging and increasing types of wealth in the modern times such as bank deposits and financial securities like shares and bonds are also zakatable (al-Qaradawi, 1999, p.333), so as to ensure that the rightful recipients are not being denied from getting their rights as well as to ensure the society in general does not suffer due to the unfair redistribution of wealth.

Zakah shall be due on all valuable items and the 'illah ${ }^{(2)}$ for zakatability is the richness (Bakar, 1998, p.3). The 'illah for zakatability should no longer be productive property, but any property which is in excess of one's personal use and his dependents. Accordingly, many modern forms of wealth and income since they are valuable property or mal should be subjected for zakah except items of personal consumption and over and above the customary needs of a person and his dependants.

The main objective of the paper is, first, to compare and contrast the concept of zakah and modern taxation especially on the legal, economic, social, ethical and spiritual aspects. Secondly, the paper aims to examine issues related to the implementation of zakah in modern time by reviewing the practices of zakah and taxation in the early Islamic period and exploring the issues in the context of Malaysia.

\section{Basic Concepts of Taxation}

Taxation can be defined as a compulsory payment to a government based on holdings of a tax base (Mikesell, 2003, p. 638). It is an important political and economic issue (Connolly \& Munro, 1999, p. 159). For a long time, governments imposed taxes to raise revenues only to cover the cost of administration and defense, and the provision of certain services by the state, and in the case of despotic monarchs the personal expenditure of the ruler (Hanson, 1972, p.556).

Nowadays, taxes are no longer imposed solely for those purposes, but also for the purposes of furthering social and economic policy. It is a compulsory contribution by people to the state to enable it to discharge its political and economic responsibilities. Abbasi (1985, pp.60-61) viewed that state and tax are complementary and one cannot survive without the other.

(1) al-Qur'an, Surah al-Ma 'arij 70:24

(2) 'Illah refers to ratio decidendi. The issue of 'illah is the most important element in Islamic law as the ruling should be always attributed to illah; whenever the 'illah exists, the rule of law will also exist and if the 'illah does not exist, the rule of law will also not exist (Bakar, 1998, p.8). 
Among other reasons for the imposition of taxes, as outlined in Hanson (1972, p.557) are: (i) to check the consumption of commodities regarded as harmful, at least if consumed to excess. It is for this reason that spirits and, to some extent, tobacco are heavily taxed, (ii) to redistribute labour, for instance to encourage labour to move from employments in one industry to other types of industry, and (iii) to reduce inequality of incomes.

There are two systems of taxation: (i) the proportional principle, and (ii) the progressive principle (Hanson, 1972, p.559). The former principle means that taxation should be proportional to income. This principle is supported by Adam Smith, the wellknown Scottish economist, as he considered it as the most equitable method of raising revenue open to the state. It was certainly, according to Hanson (1972, p.559), more equitable than equality of payment - a fixed sum per head - as in the case of some poll taxes ${ }^{(3)}$ which were prevailing during his time ${ }^{(4)}$. The latter principle (i.e. progressive principle) suggests that the amount of tax to be paid increases more than proportionately with income (emphasis added). It can be more closely related to the ability to pay, and so where great inequality of income exists it is generally regarded as being more equitable than the proportional system, for the Law of Diminishing Marginal Utility shows that the marginal utility of $£ 1$ of income is much greater to the man with an income of $£ 350$ than to one with an income of $£ 5000$ (Hanson, 1972, p. 541).

Adam Smith, an influential Western thinker, had enunciated four canons of taxation in his book The Wealth of Nations (Hanson, 1972, p.541). According to Adam Smith, the amounts people paid in taxes should be equal, by which in fact he meant proportional to their incomes. This principle basically provided that every person in the society was equal and alike for the purposes of taxation. Secondly, Smith argued that there should be certainty with regard to the amount to be paid. This principle provided the detailed and known basis to the tax-payer and tax-collector. Nothing was left to the choice or pleasure of either of the two ${ }^{(5)}$. Both knew what one is to pay and the other is to collect (Abbasi, 1985, p.61). Thirdly, there should be convenience of payment and collection $^{(6)}$. Fourthly, economy should be observed, so that taxes should not be imposed of a kind where the cost of collections was excessive. It has been estimated that in the case of some former taxes the expenses of collection absorbed as much as 85 per cent of the yield (Hanson, 1972, p. 559).

(3) By the poll taxes of $1378-80 \mathrm{AD}$ each person was not, however, equally taxed. A whole village was assessed at so much per head, but the rich paid more than the poor (Hanson, 1972, p. 559).

(4) Abu Yusuf (731-798AD), as in Sadeq (1992, p.7 in Sadeq \& Ghazali), argued for a proportional tax in agriculture, instead of a fixed levy on land, on the ground that the former was likely to yield larger revenue and facilitate expansion of land area under cultivation. This ideas was later propagated by Adam Smith during his time.

(5) Ibn Taimiyah (as cited in Islahi, 1992, p.142 in Sadeq \& Ghazali) similarly, condemns injustice on the part of both tax payers and collectors. He says: "Very often, injustice $(z u l m)$ is done by the authorities as well as their subjects, the former demand what is not justifiable and the latter deny what is due".

(6) Ibn Hazm (as cited in Ghazali,1992, p.69 in Sadeq \& Ghazali), was especially concerned over the nature of the tax collection system. Abusive and exploitative means of collecting taxes must be prevented. Taxes were to be collected by not transgressing the limits of Shariah. 
In short, Smith describes that a sound tax should reflect the ability to pay ${ }^{(7)}$, be certain and understandable, convenience to pay (to each subject) and minimum exaction (take as little from taxpayers as necessary) (Meera \& Ahsan, 1992, p.214-215). In the historical context, Smith's famous canons of taxation appear as good political advice (West, 1990, p.126) and has been accepted and determined by people with their free will and consent (Abbasi, 1985, p.61).

A basic criterion for tax-structure design is the equity objective (Meera \& Ahsan, 1992, p214). In another Smith's major work, The Theory of Moral Sentiments (1759, as cited in Muller, 1993, p.ii), he described the role of a state towards managing the financial welfare of its people: "He is certainly not a good citizen who does not wish to promote, by every means in his power, the welfare of the whole society of his fellowcitizens". As mentioned earlier, Smith is a strong proponent of the 'ability to pay' concept. Tax capacity is defined by Smith (as cited in Hollander, 1973, p.279) in terms of the total annual revenue: "The riches and so far as power depends upon riches, the power of every country, must always be in proportion to the value of its annual produce, the fund from which all taxes must ultimately be paid". Smith frequently clarified that (as cited in Hollander, 1973, p.204): "It must be remembered, however, that it is the luxurious and not the necessary expense of the inferior ranks of people that ought ever to be taxed".

\section{Zakah and Taxation in the Early Islamic Period}

Islamic states' revenues shall comprise of zakah, taxes and tariffs. Even though in al-Qur'an Allah mentioned zakah, but not taxes, majority of Islamic scholars concluded that a government may impose taxes or tariffs, besides zakah. The imposition of taxation is subject to several conditions, among others, when the treasury is not having sufficient money to cover the country's expenses (al-Qaradawi, 1999, p. 671; Hannan, n.d., p. 1). According to Ahmad (1989, p.12), Muslim jurists through the ages have accorded approval to imposition of new taxes provided the expenditures to be financed by new taxes fall in the category of essential expenditure and the tax burden is equitably distributed. It is also a requirement that the state does not spend the tax money in an extravagant or luxurious manner.

Taxation is needed and in certain situations it comes to the extent of compulsory for the state to impose taxes, where there is not enough revenues to cover for the government expenditures. This is due to zakah resources can only be utilized for specified and restricted purposes only. For many years throughout the history, governments imposed taxes because they needed to raise revenue to cover the costs of administration, national defense and security, judicial institutions, infrastructures for the purpose of public health (e.g. hospitals), public education (e.g. schools), transportation (e.g. highways), irrigation and many kinds of public facilities for the purpose of promoting social and economic policy of a state. In all these kinds of situations, the tax charge is allowed in Islam.

(7) The concept of ability to pay in the principle of taxation had been previously brought up by Abu Bakr alTartusi (450H), as cited in Sadeq (1992, p.7 in Sadeq \& Ghazali). It means that tax should be imposed only on the surplus income after meeting all the basic needs. 
Ibn Taimiyah (as cited in Islahi, 1992, p.141) argues that the Shariah sources of public revenue fall under three heads as he says: "Government revenues based on the Book and the Sunnah are three types, ghanimah, sadaqah and fay'”. Ghanimah refers to property which has been acquired from non-Muslims after a war, which is stated in surat al-Anfal of al-Qur'an. One-fifth of the spoils of war was apportioned for the state while four-fifths were generally distributed among the fighters. This was a significant source of revenue during those periods. Sadaqah here refers to zakah.

While Fay' is the booty surrendered by the enemy without actual fighting. It covers gifts presented to the head of state, tribute paid by enemy and financial penalties (Ahmad, 1989, p. 11; Islahi, 1992, p.145). Jizyah, kharaj, 'ushur and treasure trove are among them. Jizyah is a per capita financial contribution that non-Muslims were expected to make for the provision of amenities and protection that they enjoyed in an Islamic state without being obligated to fight for the defense of the state (Ahmad, 1989, p. 11). Kharaj was a tax on agricultural land located outside the Arabian Peninsula in countries conquered by Muslims. 'Ushur, on the other hand, is a type of retaliatory customs duty on goods imported by foreign merchants crossing into the Islamic state from countries where similar duty was charged from Muslim merchants. In short, it is custom duties or toll taxes imposed on traders of other countries.

According to al-Qaradawi (1999, p.671), "if the proceeds of kharaj, ghanima and fay' are sufficient, there is no need for imposing taxes, but if some sources do not exist or do not yield a sufficient amount, other taxes need to be levied, since the principle of usul $^{(8)}$ states, 'Something without which an obligation cannot be fulfilled is also obligatory'". However, in the case where for example, the tax money is collected for personal expenditure of the despotic monarchs or the ruler, it is not allowed.

In short, there is no reason why other taxes could not be collected, because after all, the purpose of zakah levy is very different from the purpose of taxation. Hannan (n.d., p.3) viewed that all sorts of taxes can be levied under the Islamic system, as long as revenues are needed for the development and defense of the country and for social welfare. Ahmad (1989, p.12) also emphasizes that the revenue (read: taxation) system of a present day state guided by Islamic teachings can differ significantly from that of the early Islamic period in respect of the composition of taxes and other details. Otherwise, some benefits of taxation difficult to derive, for example in terms of its benefit in bridging the gap between the rich and the poor in the society.

This notion is also supported by al-Qaradawi and a precedent case during Caliph Umar b. al-Khattab, where non-Muslims (i.e. Christians of Banu Taghlib) during his time requested to drop jizyah and imposes another tax with the name of Sadaqah, However, it must be borne in mind that tax is more on a matter of societal obligation, however zakah is undoubtedly the right of Allah, and thus it must come first before other obligations are being fulfilled.

(8) Usul refers to the science of figh methodology and axiomatic system. 


\section{Zakah vs. Taxation}

Shaltut (as cited in al-Qaradawi, 1999, p. 698) argued that taxes could not be counted as zakah. His view was that since zakah is a financial act of worship, it is far from being similar to taxes. Although there are certain similarities between taxation and $z a k a h$, the differences are much greater. Taxation and zakah differ in their respective legislative sources, in their theoretical foundation, their objectives, rates, exemptions, and in their expenditures. The paper proceeds with the comparison between zakah and taxation.

\subsection{Concepts}

Al-Qaradawi (1999, p.693) asserts that there is no and should never be any replacement for the term zakah. The term zakah, should be used as it is, and Muslims should not try to find an equivalent term with it, because there is none. The term zakah carries unique meanings and significance, and translating it could result to a divert in its meanings and purposes from its original context. Majeed (1993, p.21) further argues that:

"...although zakah can be said to be a kind of tax and the zakah laws canbe referred to as a system of taxation, zakah significances are many and it cannot therefore be compared to the existing secular system of taxation. Therefore, it is best that the word zakah is not translated and that Muslims should use the term zakah itself and explain its concept to non Muslims".

Any wealth below the nisab is exempted from the zakah obligation. The concept of exemption in the case of taxation is applicable only when the government or tax authorities specifically stipulate it. The concept of yearly assessment (i.e. hawl) in zakah applies to most types of wealth, excluding agriculture produce, mineral extracted and earned income

Since the obligatory nature of zakah has been prescribed in the revealed doctrine of al-Qur'an, zakah system must be upheld as a levy sanctioned by Allah on Muslims. Taxation is also liable, but not for the same reason as zakah. Taxation is a levy sanctioned by government on citizens (individuals or businesses) of a particular state through the federal laws. It is a man-made system, and as such, its source of regulation is determined by the government of the time.

The conditions of taxable assets and income plus the way to disburse tax is the prerogative of the government at the time. The same argument follows in terms of the tax structure, its rates and allowable deductions, among others. Zaim (1989, p.110) reiterated that (1) the rate and the way of payment of zakah which are clear and definite, cannot be altered: but tax is relatively changeable, and, (3) the methods of distribution and spending of zakah is definite, while tax is not. Taxation law can be amended, and can even be abolished, depending on the availability of surplus or deficit in the government's fiscal system. It should also be noted that it is relatively easier for the government to make amendments to taxation law as compared to the zakah law since the former does not have any direct relationship with revealed doctrines. 
Comparing zakah with progressive taxation, zakah was claimed as having a wider base than progressive taxation; it is imposed not only on income, but also on idle assets. The proceeds of zakah will benefit mainly and directly the poor and the needy. Hence, it will consequently raise the propensity to consume (Metwally as cited in Zaim, 1989, p.111). Zakah is also levied on productive wealth, but tax can be levied both on productive assets as well as on consumption expenditure.

\subsection{Legal Impacts}

Based on the Islamic history, during the Caliphate of Abu Bakar, a war was declared on those disputing the zakah obligation. As for the one who refrains from paying it without denying its obligation, he would be guilty of committing a sin. It is the ruler's duty to take zakah from the defaulter by force and rebuke him, provided he does not collect more than the stipulated amount. In the views of Iman Ahmad ibn Hanbal and Imam Abu Hanifah, the ruler could take half of the defaulter's money, in addition to the calculated amount of zakah, as a punishment (al-Qaradawi, 1999, p.668).

In modern taxation, tax planning is normally provided by tax consultants for individuals or companies to plan their tax liability. This is also known as tax avoidance. Tax avoidance basically means playing with the tax rules, and it is regarded as a legal activity, provided it falls within the rules and regulations. Its legality is based on the idea that every taxpayer has the right not to attract tax and to arrange his tax affair. Taxpayer would and should take advantage of any lacuna or loopholes within the tax rules.

While tax avoidance is allowed, tax evasion is not. Methods of evasion include suppressing the taxable receipts; and claiming deductions for expenditure not incurred. Evading payment of tax due by any person involves elements of offence in it. If caught, the defaulter has to pay the tax evaded and penalties ${ }^{(9)}$.

Unlike taxation, it is morally and Islamically improper for Muslims to minimize their zakah liability whether through avoidance or evasion. It is the spirit of zakah that it should be paid on the real net worth of a person's wealth. Evasion is a real possibility in tax, but zakah is paid by the believer as a form of worship (Zaim, 1989, p.111). In a pure Islamic state, such tricks and behaviors would be a serious crime against the society and thus, a punishable offence. It is against the spirit of Quranic injunctions since the offender is trying to deny Allah's rights. In the absence of an Islamic state, the individual has to be careful, as Allah knows our deepest thoughts and intentions.

In some Islamic countries, certain preventive measures in the form of incentives for the zakah payer have been undertaken by its government. For instance, in Malaysia, the tax authority under the federal government grant a tax rebate, if a Muslim had paid zakah. As an example; a Muslim made zakah payment to the authority of RM1000, this RM1000 is treated as a rebate of tax that is set against his total tax that is due. In other words, he obtains a 100 percent relief for the zakah payment. This is considered as a

(9) Ibn Taimiyah (as cited in Islahi, 1992, p. 142 in Sadeq \& Ghazali), forbids tax evasion, especially when the tax is levied collectively on a group or community, even when the tax is unjust. The reason for this is that, if a person evades his share of tax, that share will fall on the others in the group, who will thus have an even greater and more unjust burden to carry. 
pro-active effort towards the development of the zakah system. This will partly minimize the burden among the Muslims for having to pay both zakah and tax.

\subsection{Economic and Social Impacts}

Zakah occupies an important place in Islamic economics. It serves as a unique mechanism of compulsory transfers of income and wealth from the haves to the have nots in the community (Miah, 1992, p.153). Through this, each and every individual in the society are assured of minimum means of livelihood, which provides social security system in an Islamic society (Ahmad, 1989, p.6).

Throughout history, whenever Muslims truthfully applied the system of zakah, as ordained by Allah and His messenger, the splendid objectives of zakah were fulfilled and its great efforts appeared within the lives of the individuals and the society. One excellent example is during the Caliphate of Umar b. Abdul Aziz whereby the zakah system was so successful that it became difficult to find even one needy person to receive the zakah collection. This shows how zakah, if implemented properly could make wonders to the society. Sayyid Sabiq (1991, p.xvi) has brought up this point very eloquently when he said:

"What is remarkable about zakah is that it finishes a job that taxation, to begin with, cannot accomplish”.

One similarity between zakah and taxation is whereby both have to be paid though no direct and equivalent economic benefit obtained by the zakah and tax payer. Zakah payers are expected to get the reward and the returns in the hereafter while tax payers may receive some service in return but there is no direct co-relation (Hannan, n.d., p.1).

Hanson (1972, p.546-8) identified various negative economic effects of taxation. These include a deterrent to work, a deterrent to saving, a deterrent to enterprise, taxation may also encourage inflation, and diversion of economics resources. As such, taxation, above a certain level, can be economically disadvantageous. Similarly, Ibn Khaldun (1332-1406 AD) (as cited in Sadeq, 1992, p.7, in Sadeq \& Ghazali) argued that work efforts will be affected by high taxes resulting a decrease in production and population (due to emigration), which will eventually decrease tax revenue by decreasing the tax base. Ibn Khaldun's assertion is strongly agreed by many Islamic scholars such as Siddiqi (1992b, p.48 in Sadeq \& Ghazali), where when government (consumption) expenditure increases and more taxes are levied, economic growth is adversely affected, eventually leading to a decline (see also Issawi, 1992, p.224 in Sadeq \& Ghazali).

The additional (or excessive) taxation would produce economically harmful results that outweigh the gain to the community from the use of the money raised by taxation (Hanson, 1972, p.549). The same suggestion had been provided much earlier by Ibn Khaldun (1332-1406 AD), (as cited by Siddiqi, 1992a, p.23 in Sadeq \& Ghazali):

"The most powerful factor contributing to population and civilization is minimization of the quantity of taxes on the people to the extent feasible. This gives incentive to people as they feel confidence by realizing the benefits of civilization". 
Tax burden is able to be transferred by the tax payer to the consumer or producer (Zaim, 1989, p.111). However, in zakah, there is no such transfer of zakah burden. AlMaqrizi (1364-1441 AD), (as cited in Sadeq, 1992, p.7, in Sadeq \& Ghazali) analysed the problem of tax burden. According to him, if tax is not efficiently handled, tax burden may be shifted to consumers, whereas it is supposed to be borne by the producers and business men from the profit income. A consequence, according to him, is the fall in demand for the goods concerned because of their higher tax adjusted prices, which in turn affects the suppliers and the economy as a whole.

There are many impacts of zakah which include the incentive to produce, incentive to invest, incentive to save, incentive to consume, playing a role in redistribution of income/assets, incentive to work, as a control of business fluctuation, and as a redirection of investment (Ataul Haq, 1993, p.12-20; Miah, 1992, p.121; Ahmad, 1989, p.20-25). Zakah also has a multiplier effect to the economy; some Muslim economists believe that a certain amount of zakah funds invested according to the overall production priorities of an economy would benefit the poor in particular and the economy, in general, through its multiplier effect on employment and incomes (Zaim, 1989 , p.117). In this way it would gradually eliminate poverty instead of providing recurring financial support to the same set of people. Consequently, employment and income will be increased in the economy thereby increasing the standard of living of the people and eventually it would enhance the aggregate volume of zakah collection.

If zakah is properly managed, the government may be relieved from significant social welfare expenditure. Thus, resort to taxation can be kept to a minimum in an Islamic economy. In addition, Sadeq (1992, p.9, as cited in Sadeq \& Ghazali) rightly emphasized that zakah is a sub-set and integral part of the social security system which is built in the Islamic economic system, to help the less-priviledged group such as poor, needy, unemployed, orphans, handicapped and so on. In a more elaborate manner, Mawdudi (1975, p.35) regarded zakah as, in fact, the best form of insurance for the society and destroys all the evils which arise from the absence of any regular arrangement for collective help and cooperation. Mawdudi pointed out that what really forces a man, in the capitalistic system, to accumulate wealth and invest it in profitable business and bring into existence institutions like the life insurance, is that under this system every one's life is wholly dependant on his own means. This view has also been emphasized by Sharif (1976, p.171) that zakah in the Muslim constitution of the Caliphate days was so comprehensive and broad-based that it not only promoted socialistic redistribution of wealth but also tended to create a healthy non-capitalistic frame of mind and a collective spirit.

\subsection{Ethical and Spiritual Impacts}

Al-Ghazali (1983, p.53-73), in his treatise Ihya 'Ulum al-Din has outlined eight inward attitudes and duties that are incumbent on those who seek, through payment of their alms (read zakah), the way that leads to the Hereafter. These include (1) understand the purpose and significance of zakah, (2) payment at proper time, (3) give in secret , (4) give openly, (5) avoid taunting and hurting, (6) adopt humility, (7) give the best and the dearest and (8) seek the worthy and deserving. 
Zakah, according to al-Ghazali, is a measure to test our degree of love to Allah. AlQuran considers possession of wealth a trying test, and not a token of virtuous excellence or privileged nobility or a means of exploitation ${ }^{(10)}$ (Abdalati, 1980, p.128). Al-Ghazali (1997, p.80-81) argued that:

"Our property which is very dear to us, is God's trust deposited with us. Therefore, it is necessary that they should be sacrificed in His cause, and they should be utilized for seeking His pleasure. If you suffer a loss in them, you should not start crying and wailing and you should not consider that it was your personal property that has been taken away from you, because compared to you Allah is the more rightful owner and He has the right to use it in any way He likes. If you are tested by an increase in them, then you should not hesitate to undertake jihad when called upon to do so, and you should not turn away from obedience to Allah on account of them,"(11).

In Islam, the real owner of wealth is God alone and the proprietor is simply an appointed agent and a mere trustee (Abdalati, 1980, p.130). In explaining the concept of trust, al-Ghazali (1983, p.73) mentioned that in the eyes of Shariah, trust has a very broad sense. This word contains an ocean of meaning, but underneath it is the sense of responsibility, the sense of having to appear before Allah and to account for one's actions. The details regarding the concept of amanah (trust and responsibility) in Islam as provided by the hadith:

"Everyone of you is a guardian and everyone will be asked about his subjects. The Imam is a guardian. He will be asked about his subjects. A man is the guardian of the persons in his household. He is answerable about them. A woman is the guardian of her husband's house. She will be asked about her responsibility. The servant is the guardian of the articles of his master. He is answerable about this responsibility of his" (al-Bukhari)

Zakah is also considered as an expression of gratitude to God's bounties. Zakah payment should be done once it becomes due and should not be procrastinated. The best is that we perform the duty secretly, unless we want others to follow suit our good deeds. Most importantly, we should not feel arrogant and we should not hurt the feelings of the recipient. In terms of giving the best and the dearest, we can apply this in the context of how we perceived wealth and money. Al-Ghazali (1997, p.80) emphasized that wealth given by Allah is a trust (the concept of trustworthy). Proprietors are constantly reminded of the fact that they are in reality mere agents appointed by God to administer their holdings. However, Islam did not prevent the Muslims from attaining wealth and endeavoring for material improvements through lawful means.

In terms of distributing zakah, we must ensure that the most worthy and deserving in the society will benefit from our duty fulfillment. Accordingly, Abdalati (1980,

(10) al-Quran, Surah al-An'am 6: 165.

(11) al-Quran, Surah al-Anfal 8: 27-28. 
p.128) emphasized that the proprietor must always be ready to spend in the way of God and to contribute to worthy causes. It makes him responsive to the needs of the society and gives him an important role to play, a sacred mission to fulfill.

In the case of taxation, the element of reluctance and rancour is underlying. This is so because tax payer is not moved by the conviction that the levy is from Allah, who will then recompensate him for it (Shad, 1986, p.44). Even in the so-called advanced societies where the role of taxation in the modern-day state is very well understood, there is a perennial conflict of interests between the tax giver and the recipient. The question 'Why should I support social programs?' continues popping up in different forms and debates" (Sayyid Sabiq, 1991, p.xvi).

The above situation could negatively impact the smooth-running of the tax system, plus, it would affect the accomplishment of the tax objectives. Even though various measures have been undertaken through various means of transfer payments, for instance, through providing facilities to the people, taxation system is still unable to bridge the said gap, until and unless moral aspects is incorporated and inculcated within the mind and hearts of the payers. Thus, ideally, in order to ensure the taxation system derives its utmost benefit; its compliance should come along with the moral ethics and spiritual involvement of the payer. This perhaps could help in achieving the indirect benefits from taxation.

Zakah, on the other hand, does not carry such problems because it does not ignore the human context of human relations. It is man who is at the heart of its program. It also involves spiritual implications as fully and comprehensively as any other mode and manner of worship prescribed as fundamental pillar of Islam would do (Abbasi, 1985, p.59).

Taxation may not be significant to the tax payer other than it saves him from fines and prison term (Majeed, 1993, p.21). Taxation has primarily legal and economic incentives and implications, as compared to moral and spiritual incentives, unlike in the case of zakah. Modern taxation merely looks at the compliance of a citizen to his or her country's laws and regulations. This also has been supported by Zaim (1989, p.110), where he stated that taxation is a financial responsibility while zakah is a religious duty and worship in terms of finance.

Despite the fact that taxation is a social obligation without having special sense of gratitude to Allah or to obtain nearness to Allah, it has to be borne in mind that as a citizen in a particular country, once the state imposed tax, as long as it is for legitimate reasons, and will be used in a legitimate ways, Muslims will become obliged and responsible to pay tax imposed on them.

Majeed (1993, p.21) had addressed the issue that zakah has important moral and spiritual dimensions as compared to tax, which is only concerned with the monetary effects:

“...in most situation, taxpayers pay their tax reluctantly and try to seek every deduction they can possibly get. On the other hand, zakah givers are supposed to give their zakah willingly. They should feel eager to fulfil their obligation of giving zakah to please Allah. This is because zakah giving is an act of submission". 


\subsection{Issues on the Implementation of Zakah and Taxation: the Case of Malaysia}

From the preceding section, it shows that an Islamic state has the right to charge other levies, besides zakah, on its citizens. However, as reflected in most Muslim countries' fiscal systems, they seem to regard taxation as more important compared to zakah. Taxation system becomes an integral part of the fiscal system, whereas zakah becomes just a voluntary institution. This prevailing practice in Muslims countries could be contributed by the colonialist influence over the Muslims lands. Many contemporary Islamic scholars raise the above issues and try to promote a true Islamic institution such as zakah to play its prominent role as a divine practice in true Muslim societies.

Al-Qaradawi, in his monumental work, Fiqh al-Zakah (Law of Zakah), argued that taxes do not make up for zakah, since zakah, as pillar of Islam, must not be forgotten in the actual practice. Sincere Muslims must pay zakah in addition to taxes which they are obliged to pay by law. This is one way of striving for the re-establishment of this religion on earth. Al-Qaradawi (1999, p.700) further asserts that the legal and economic situation in Muslim countries must be brought back to compliance with the Islamic system. Without enormous effort to reform Muslim societies under the guidance of the Islamic system, Muslims will remain financially, psychologically, and socially burdened.

Nik Hassan (1991, p.217), in describing the position of zakah in Malaysian fiscal management, had pointed out that:

"There is no synchronization between these two functions. The only relation between zakah and the country's fiscal management is through the provision in the tax system that zakah payers can obtain tax rebate for the amount contributed as zakah. Thus, the zakah system has no significant place in the Malaysian fiscal system. It is seen solely as a 'religious' activity, and the running of the economy is considered as a mundane responsibility. Islam is seen as a religion in the Western sense and not as a complete system that governs the whole spectrum of the country's management".

The above can be attributed to the historical background of the Federal Constitution in Malaysia. The Constitution recognized religious affairs as state matters, rather than federal matters (refer to the Ninth schedule of Malaysian Federal Constitution). Thus, the administration of zakah in Malaysia is under the jurisdiction of the respective states or the prerogative of the rulers (Sultan) of the respective states, except in Federal Territory whereby the zakah law and administration are governed by the Federal government (Bakar, 1998, p.13). Consequently, all aspects pertaining to the administration of zakah are handled by the states through its respective Majlis Agama Islam Negeri (State Islamic Religious Councils) ${ }^{(12)}$, while the fiscal management of the country is a federal matter.

(12) There are a total of fourteen State Islamic Religious Councils (SIRCs). One for each of the thirteen states and one for the Federal Territory of Kuala Lumpur, Labuan and Putrajaya. These SIRCs have a unique status in that they are not part of the Federal or State government (Pusat Pungutan Zakah, n.d., p.5). 
In other states except for Federal Territory, the most that the Federal government can do is basically to coordinate the zakah matters amongst the states, but they have no ultimate power to intervene into the respective states' zakah matters, in specific or religious matters, in general. Even though the Federal Territory did establish Department of Islamic Development (i.e. JAKIM) under the Prime Minister's Department to coordinate and bring some form of uniformity into the administration of Islam in Malaysia, its function remains purely advisory in nature. In addition to that, the recently established Department of Zakah, Waqaf and Hajj also has a very limited role in monitoring the zakah practices in Malaysia.

Even though each state has its own state enactment which outlines the rules and regulations pertaining to zakah, it is very unfortunate that they are still lagging behind in terms of the law enforcement. A state government is apparently a less credible authority (as compared to federal government) in terms of the enforcement of laws. This is one of the many reasons contributing to this phenomenon. As a consequence of the above, zakah become just as a voluntary payment system. However, taxation is a highly regulated system enforced by the Federal government. Proper penalty can be imposed on the tax defaulters, and as such the compliance to the tax regulation has been perceived as more important as compared to the compliance to zakah laws.

In terms of incentive the Malaysian government has provided at least two incentives in their effort to promote zakah payment. Firstly, as discussed earlier, the tax authority under the federal government granted an income tax rebate, for individual Muslim who had paid zakah to SIRCs. Secondly, for companies, in the 2005 Malaysian Government Budget, it had been announced that any zakah which is paid by company to SIRCs will be granted as an allowable deduction in the computation of the corporate tax. However, the amount of deduction is limited to 2.5 per cent of the aggregate income.

The above exemption is very minimal. Abdul Rahman (2005, p.7) argued that this so-called 'partial rebate' for business entities should be replaced by full corporate tax rebate, in the same way rebate be granted to individual Muslims who paid zakah. He further explained that:

"If government allows companies that pay zakah on business wealth to claim rebate from their tax liability, this will consequently ease their financial burden. Furthermore, the tax rebate will serve as an incentive for Muslim majority owned companies which have not paid in the past to pay zakah on business wealth".

This argument, however, need to be studied thoroughly, if it were to be enforced. One of the possible repercussions, according to Amin (2003, p.19), is that the government would relinquish a material sum in annual income tax from the business sector. 


\section{Conclusion}

The paper indicates that zakah greatly differs from the taxation system. Zakah aims not only to achieve religious merit, but also aims to become part of the modern state fiscal policies and shares a greater role in removing inequalities in society. The paper argues that there may be lack of proper implementation of zakah in Muslim countries and, thus, limits the success of the noble aims of the zakah system. The paper indicates the urgent need for education and political will of modern governments in order to ensure the success and survival of the zakah system. Further studies are needed to empirically document the successes and shortcomings of the implementation of zakah in modern Muslim countries and evaluate factors that may influence or impede the implementation of zakah. Studies are also greatly needed to evaluate the level of knowledge of zakah, especially among the Muslims, in order to assess future education needs and strategies to enhance the knowledge about zakah.

\section{Bibliography}

Abbasi, M.A. (1985) Zakah vs. Tax, Islamic Order, Vol. 7, No.2, pp. 59-62.

Abdalati, H. (1980) Islam in Focus, Islamic Teaching Centre, Riyadh, pp. 126-129.

Abdul Rahman, A.R. (2005) Pre-Requisites for Effective Integration of Zakah into the Mainstream Islamic Financial System in Malaysia, Seminar Zakah Korporat. Organized by Pusat Zakah Selangor, Petaling Jaya, 22 and 23 June.

Abdullah Yusuf Ali (1989) The Holy Quran: Text, Translation and Commentary. Amana Corporation, Washington

Ahmad, S.M. (1977) Economics of Islam: A Comparative Study, S.M.A, Lahore.

Ahmad, Z. (1989) Public Finance in Islam, International Monetary Fund Working Paper, Islamabad, Pakistan.

Amin, Iszuddin Mohd (2003) Business Zakah Poised for Take-Off, Akauntan Nasional, January/February, pp.18-20.

Ataul Haq, Pramanik (1993) Development and Distribution in Islam, Pelanduk Publications, Kuala Lumpur.

Bakar, M.D. (1998) The Malaysian Zakah System: Law and Policy Reform, Seminar on Zakah and Taxation, Organized by Kulliyah of Economics and Management, International Islamic University Malaysia, 8-9 June.

Connolly, S. and Munro, A. (1999) Economics of the Public Sector, Prentice Hall, England.

Ghazali, A. (1992) "Economic Thought of Ibn Hazm" in Sadeq and Ghazali (edit), pp. 66-73.

al-Ghazali, M. (1983) Inner Dimensions of Islamic Worship, Trans. By Muhtar Holland, The Islamic Foundation, London.

al-Ghazali, M. (1997) Muslim's Character, International Islamic Federation of Student Organizations, International Islamic Publishing House, Riyadh.

Hanson, J.L. (1972) A Textbook of Economics, Sixth Edition, Macdonald and Evans, London.

Hollander, S. (1973) The Economics of Adam Smith, Heinemann, Canada.

Islahi, A.A. (1992) Economic Concepts of Ibn Taimiyyah. in: Sadeq, A.M. and Ghazali, A. (edit.). Issues in Islamic Economics: Readings in Islamic Economic Thought: pp. 119-156, Longman: Malaysia

Issawi, C. (1992) Ibn Khaldun's Analysis of Economic Issues, in: Sadeq, A.M. and Ghazali, A. (edit.), Issues in Islamic Economics: Readings in Islamic Economic Thought, pp.222-237, Longman, Malaysia.

Majeed, F.S.A. (1993) Zakaat: Questions and Answers, Vol. 2, Ze Majeed's Publishing, Singapore.

Mawdudi, S.A.A. (1975) The Economic Problem of Man and Its Islamic Solution, Islamic Publications, Lahore. 
Meera, A.K.M. and Ahsan, S.N. (1992) Al-Kharaj and Related Issues: A Comparative Study of Early Islamic Scholarly Thought and their Receptiveness by Western Economists, in: Sadeq, A.M. and Ghazali, A. (edit.), Issues in Islamic Economics: Readings in Islamic Economic Thought: pp.203-221, Longman, Kuala Lumpur.

Miah, Muhammad Solaiman (1992) A Study on Distribution of Income and Wealth in Islam with Special Reference to the Institution of Zakah, Unpublished PhD Thesis, International Islamic University Malaysia, Petaling Jaya.

Mikesell, J.L. (2003) Fiscal Administration: Analysis and Applications, Sixth Edition, Wadsworth Publishers, California.

Muller, J.Z. (1993) Adam Smith in His Time and Ours, Free Press, New York.

Nik Hassan, N.M. (1991) Zakah in Malaysia: Present and Future Status, Ins. Sadeq, Pramanik and Nik Hassan (edit), Development and Finance in Islam, International Islamic University Press, Malaysia, pp. 213-238.

Pusat Pungutan Zakah (undated) Zakah in Malaysia. Pusat Pungutan Zakah Wilayah Persekutuan, Kuala Lumpur.

al-Qaradawi, Yusuf (1999) Fiqh az-Zakah: A Comparative Study-The Rules, Regulations and Philosophy of Zakah in the Light of the Qur'an and Sunna, Dar Al Taqwa Ltd., London.

Sabiq, Sayyid (1991) Fiqh us-Sunnah: Az-Zakah and As-Siyam, vol. .3, American Trust Publications, Washington.

Sadeq, A.H.M. (1992) "Introduction: Islamic Economic Thought", in: Sadeq, A.M. and Ghazali, G. (edit.), Issues in Islamic Economics: Readings in Islamic Economic Thought, pp.1-13, Longman, Malaysia.

Shad, Abdur Rahman (1986) Zakah and Ushr, Kazi Publications, Lahore.

Sharif, M.R. (1976), Islamic Social Framework, Sh. Ashraf, Lahore.

Siddiqi, M.N. (1992a) Islamic Economic Thought: Foundations, Evolution and Needed Direction, in: Sadeq, A.M. and Ghazali, A. (edit.), Issues in Islamic Economics: Readings in Islamic Economic Thought, pp.14-32, Longman, Malaysia.

Siddiqi, M.N. (1992b) Recent Works on History of Economic Thought in Islam: A Survey, in: Sadeq, A.M. and Ghazali, A. (edit.), Issues in Islamic Economics: Readings in Islamic Economic Thought, pp.33-58, Longman, Malaysia.

West, E.G. (1990) Adam Smith and Modern Economics: From Market Behaviour to Public Choice, Edward Elgar, England.

Zaim, Sabahaddin (1989) Recent Interpretations on Economic Aspect of Zakah. in: Imtiazi, I.A., et. Al., (edits), Management of Zakah in Modern Muslim Society. IRTI/IDB: Jeddah, pp. 101-120. 


\title{
الزكاة و الضر ائب المعاصرة: در اسة مقارنة
}

\author{
نور بريزة أبوبكر و عبدالرحيم عبدالرحمن

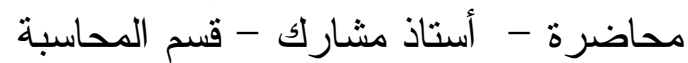

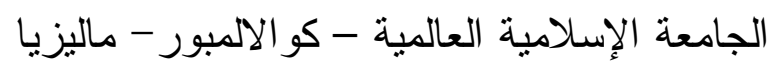

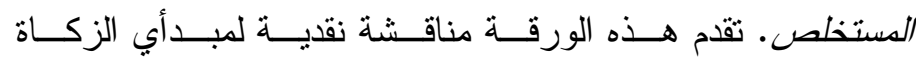

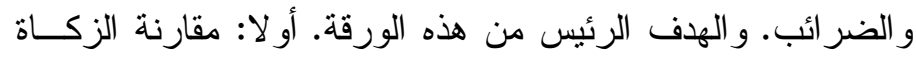

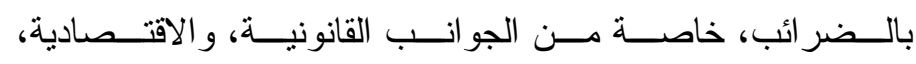

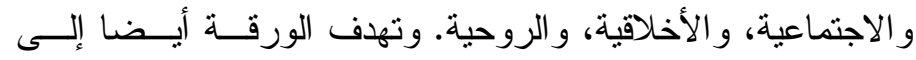

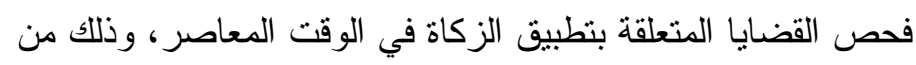

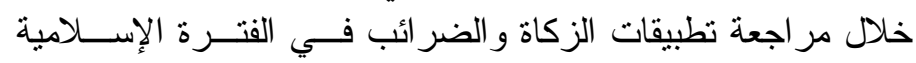

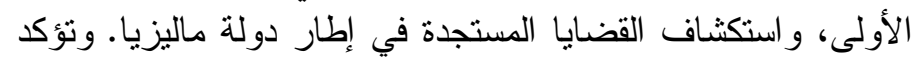

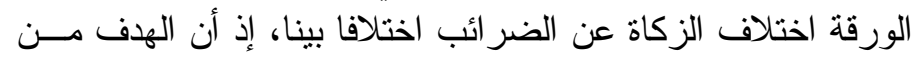

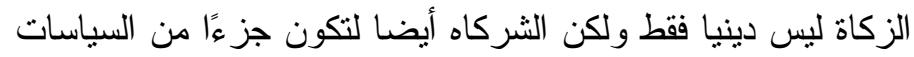

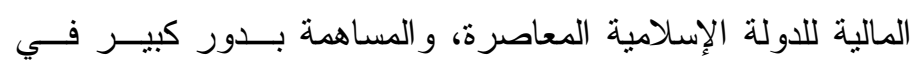

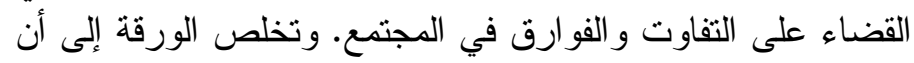

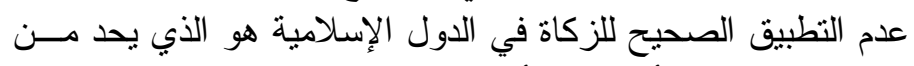

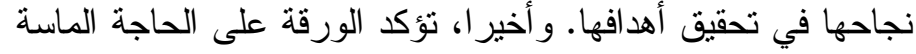

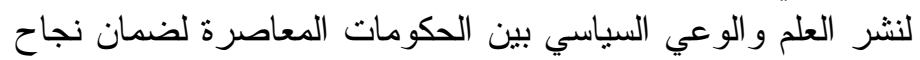

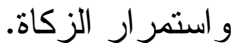

